\title{
Caspase-3 activity is present in cerebrospinal fluid from patients with traumatic brain injury
}

\author{
Luc Härter $^{\mathrm{a}, *}$, Marius Keel ${ }^{\mathrm{a}}$, Hannes Hentze ${ }^{\mathrm{b}}$, Marcel Leist ${ }^{\mathrm{c}}$, Wolfgang Ertel ${ }^{\mathrm{a}}$ \\ a Department of Trauma Surgery, University Hospital Zürich, Zürich, Switzerland \\ ${ }^{\mathrm{b}}$ Institute of Molecular and Cell Biology, 117609 Singapore, Singapore \\ ${ }^{\mathrm{c}}$ H. Lundbeck A / S, 2500 Valby, Denmark
}

\begin{abstract}
Loss of neurons after traumatic brain injury (TBI) might involve dysregulated apoptosis. Activation of caspase-3 is one hallmark of apoptosis. Therefore, caspase-3 activity (cleavage of DEVD-afc) was measured in cerebrospinal fluid (CSF) samples $(n=113)$ from 27 patients with TBI at day 1 t0 14 after trauma. Caspase-3 activity was detected in 31 (27.4\%) CSF samples with highest values ( $>5.5$ $\mu \mathrm{M} / \mathrm{min}$ ) seen at day 2-5 after trauma. No caspase-3 activity was found in serum from patients or CSF from controls. The presence of activated caspase-3 in CSF suggests ongoing apoptotic processes during traumatic brain injury. C 2001 Elsevier Science B.V. All rights reserved.
\end{abstract}

Keywords: Apoptosis; Neurons; Trauma; Brain; DEVD-afc; zVAD

Neuronal cell loss after traumatic brain injury (TBI) has been formerly attributed to necrosis of neurons as a result of secondary insults. More recent evidence from animal models (Rink et al., 1995) and findings in human patient tissues (Ng et al., 2000; Clark et al., 1999) point towards an involvement of apoptosis in the mechanism of neuronal destruction following TBI. Apoptosis in neurons, endothelial cells, and astrocytes is triggered through the CD95 system (Leist and Nicotera, 1998). Because high concentrations of CD95-ligand were found in cerebrospinal fluid (CSF) from patients with severe TBI (Ertel et al., 1997), this points to the involvement of apoptotic processes responsible for brain damage following TBI.

A group of intracellular cysteine proteases, called caspases has been shown to play a pivotal role in the regulation and execution of apoptosis. Within this group, caspase-3 is the main executioner protease and its activation marks a point-of-no-return in the complicated cascade of apoptosis induction. Thus, the presence of active caspase- 3 is a good indicator of apoptosis. To date, it is unknown whether active caspase-3 can be released from cells dying by apoptosis into CSF following TBI.

Therefore, caspase- 3 activity was examined in the CSF of 27 patients with severe TBI. All patients were treated

Konstanzer Online-Publikations-System (KOPS)

URN: http://nbn-resolving.de/urn:nbn:de:bsz:352-opus-82304

URL: http://kops.ub.uni-konstanz.de/volltexte/2009/8230/ according to our standard protocol for TBI (Stocker et al., 1995), which was approved by the University Hospital Medical Ethics Board. Three patients (11.1\%) succumbed to death due to TBI. As a control, the CSF from seven patients requiring spinal anesthesia for elective orthopedic surgery (with normal CSF protein content and cell count) were included in this study after written informed consent. The control group was comparable to the trauma patients with regard to age and gender (Table 1).

CSF drained from an indwelling ventricular catheter was collected from all patients each day at 8 am between days 1 and 14 after trauma. However, in some patients, it was not possible to obtain CSF on consecutive days due to failure of the intraventricular catheter, collapsed ventricles due to extensive brain edema or death of the patient. The preflow $(0,5 \mathrm{ml})$ was discarded and $1-2 \mathrm{ml}$ of the sterile CSF centrifuged $\left(300 \times g, 10 \mathrm{~min}, 4^{\circ} \mathrm{C}\right)$ and then frozen immediately at $-80{ }^{\circ} \mathrm{C}$ until further processing.

Caspase-3 activity in the CSF was measured by a fluorimetric assay based on the specific hydrolysis of DEVD-7-amino-4-trifluromethylcoumarin (DEVD-afc, 60 $\mu \mathrm{M})$ in substrate buffer (50 mM HEPES, $\mathrm{pH} 7.4,1 \%$ sucrose, $0.1 \%$ Chaps, $10 \mathrm{mM}$ DDT, Thornberry, 1994). Caspase-3 activity ( $\mu \mathrm{M}$ afc/min) was determined by measuring the increase of afc-fluorescence (excitation at 385 $\mathrm{nm}$; fluorescence emission at $505 \mathrm{~nm}$ ) over $30 \mathrm{~min}$ at 37 ${ }^{\circ} \mathrm{C}$, and calculation of the afc formation/time based on an 
Table 1

Demographic data of patients and controls

\begin{tabular}{llllllll}
\hline Group & $n$ & Age $^{\mathrm{a}}$ & Gender $^{\mathrm{b}}$ & Mortality & AIS & ISS & GCS \\
\hline Patients & 27 & $36.1 \pm 12.9$ & $24 / 3$ & $11.1 \%$ & $4.8 \pm 0.4$ & $29.2 \pm 11.9$ & $7.9 \pm 4.2$ \\
Controls & 7 & $41.6 \pm 9.8$ & $6 / 1$ & - & - & - & - \\
\hline
\end{tabular}

AIS: abbreviated injury score (points), ISS: injury severity score (points). GCS: Glasgow coma scale (points).

${ }^{a}$ Mean age \pm SD.

${ }^{\mathrm{b}}$ Gender is given as male/female.

afc standard curve. The specificity of the assay for caspase- 3 activity was confirmed by the block of fluorescence increase when samples were re-measured in the presence of the caspase inhibitors DEVD-CHO $(1 \mu \mathrm{M})$ or zVADfmk $(5 \mu \mathrm{M})$. Recovery $(105 \pm 10 \%$ at a mixture of sample:caspase-3 (300 $\mu \mathrm{M} / \mathrm{min})$ of $96: 4)$ and sensitivity ( $\geq$ $0.5 \mu \mathrm{M} / \mathrm{min}$ ) of the assay was regularly controlled by addition of active recombinant human caspase-3 to control CSF samples.

Caspase-3 activity was detected in 31 of $113(27.4 \%)$ CSF samples from 20 out of 27 patients $(74.1 \%)$ with TBI (Fig. 1). The highest levels of caspase-3 activity were detected between day $2(6.5 \mu \mathrm{M} / \mathrm{min})$, day 4 (5.5 $\mu \mathrm{M} / \mathrm{min})$ and day $5(6.3 \mu \mathrm{M} / \mathrm{min})$ after trauma and declined thereafter. In contrast to CSF from patients, caspase-3 activity was undetectable in CSF from the seven controls or in parallel serum samples from patients and controls despite addition of DTT (10 mM) to the samples which is known to reactivate caspases previously inactivated by mild oxidants or nitric oxide (NO).

The data presented here show that caspase- 3 activity is present in CSF of patients with severe TBI, indicating the involvement of apoptotic processes in the brain following

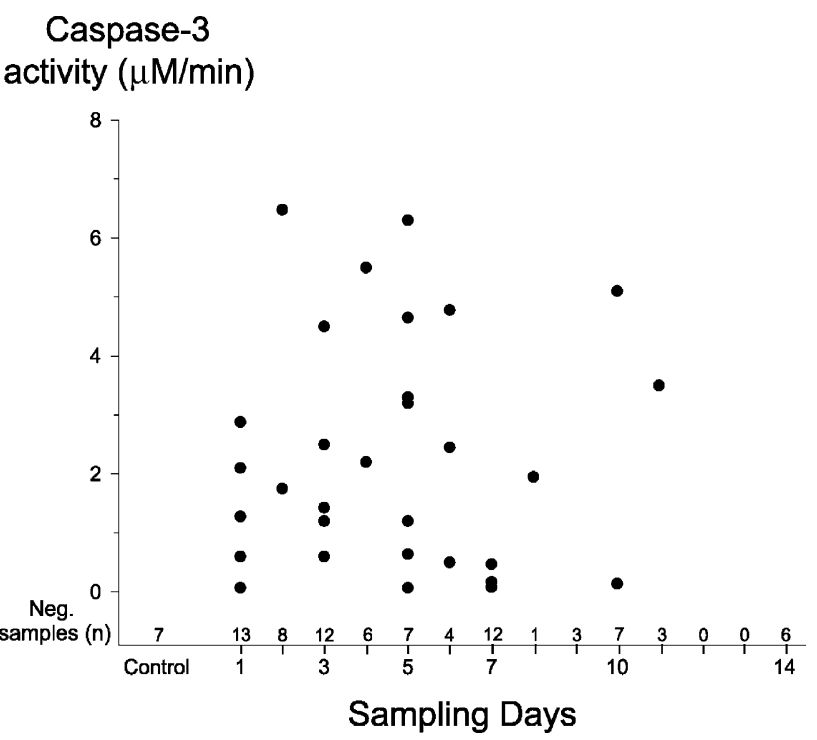

Fig. 1. Caspase-3 activity in CSF from patients with severe traumatic brain injury compared to controls. Sterile CSF was collected from patients between day 1 and 14 after trauma and from controls and immediately frozen until measurement of caspase-3 activity $(\mu \mathrm{M} / \mathrm{min})$.
TBI. Undetectable caspase-3 activity in the circulation excludes secondary migration of caspase- 3 through the blood-brain barrier. The identification of the mode of death in human TBI has been complicated by the fact that only post mortem material can be used where the mechanisms of death are difficult to study. Since the only form of cell death associated with caspase-3 activation is apoptosis (Leist and Jäättelä, 2001), the observation of increased activity of this protease in CSF of patients adds further evidence for the contribution of apoptosis to TBI. Thus, our results refute arguments that caspase- 3 detected in post-mortem brain tissues from patients with TBI were a post-mortem artifact (Love et al., 2000).

Sampling of CSF has been used frequently as a minimally invasive method or readily available source to draw conclusions on the state of injury to the brain, and to obtain markers of predictive or diagnostic value. Besides various cytokines indicating inflammatory processes, also increased concentrations of the apoptosis-inducing CD95L have been detected (Ertel et al., 1997). This finding is now complemented by even closer evidence of ongoing apoptotic processes indicated by the release of activated caspase-3. It should be emphasized that our results do not allow localization or identification of specific cells undergoing apoptosis in the injured brain or differentiation between active involvement of caspase- 3 and its release due to cell death. Although preliminary, our study demonstrates for the first time the presence of active caspase- 3 in CSF from patients with severe head injuries.

\section{Acknowledgements}

We thank Heike Naumann and Andreas Rassow for expert technical assistance. This work was supported by grant 32-52932.97 from the Swiss National Science Foundation.

\section{References}

Clark, R.S., Kochanek, P.M., Chen, M., Watkins, S.C., Marion, D.W., Chen, J., Hamilton, R.L., Loeffert, J.E., Graham, S.H., 1999. Increases in Bcl-2 and cleavage of caspase-1 and caspase-3 in human brain after head injury. FASEB J. 13, 813-821.

Ertel, W., Keel, M., Stocker, R., Imhof, H.G., Leist, M., Steckholzer, U., Tanaka, M., Trentz, O., Nagata, S., 1997. Detectable concentrations 
of Fas ligand in cerebrospinal fluid after severe head injury. J. Neuroimmunol. 80, 93-96.

Leist, M., Nicotera, P., 1998. Apoptosis versus necrosis: the shape of neuronal cell death. Results Probl. Cell Differ. 24, 105-135.

Leist, M., Jäättelä, M., 2001. Nat. Rev. Mol. Cell. Biol. 2 (8), 1-12.

Love, S., Barber, R., Wilcock, G.K., 2000. Neuronal death in brain infarcts in man. Neuropathol. Appl. Neurobiol. 26, 55-66.

Ng, I., Yeo, T.T., Tang, W.Y., Soong, R., Ng, P.Y., Smith, D.R., 2000. Apoptosis occurs after cerebral contusions in humans. Neurosurgery 46, 949-956.
Rink, A., Fung, K.M., Trojanowski, J.Q., Lee, V.M., Neugebauer, E., McIntosh, T.K., 1995. Evidence of apoptotic cell death after experimental traumatic brain injury in the rat. Am. J. Pathol. 147, 15751583.

Stocker, R., Bernays, R., Kossmann, T., Imhof, H.G., 1995. Monitoring and treatment of acute head injury. Update Intensive Care Emerg. Med. 22, 196-210.

Thornberry, N.A., 1994. Interleukin-1beta converting enzyme. Methods Enzymol. 244, 615-631. 